\title{
Fuat Sezgin'in 1 Ağustos 1957 Tarihli Raporunda Din Adamları ve Dini Yaşantıya Yönelik Görüşleri
}

\author{
Mehmet Özalper ${ }^{a, *}$ \\ ${ }^{a}$ Dr. Öğr. Üyesi, Muş Alparslan Üniversitesi, Fen-Edebiyat Fakültesi, Tarih Bölümü, 49250, Muş/Türkiye. \\ ORCID: 0000-0003-2758-5873
}

Fuat Sezgin's Views on Religious Officials and Religious Life in the Report Dated 1 August 1957

\section{MAKALE BİLGISII}

Makale Geçmişi:

Başvuru tarihi: 01 Kasım 2020

Düzeltme tarihi: 04 Kasım 2020

Kabul tarihi: 05 Kasım 2020

Anahtar Kelimeler:

Türkiye Cumhuriyeti

Yenileşme

Fuat Sezgin

Din

Diyanet İşleri Teşkilatı

\section{ART ICLEINFO}

Article history:

Received 01 November 2020

Received in revised form 04 November 2020

Accepted 05 November 2020

\section{Keywords:}

Republic of Turkey

Innovation

Fuat Sezgin

Religion

Religious Affairs Organization
ÖZ

Toplumlarda kültürü oluşturan öğeler arasında iklim, coğrafya, tarih, edebiyat, sanat, dil ve din gibi çeşitli hususlar mevcuttur. Her biri bu oluşumda büyük bir önem arz etmektedir. Ancak din hususu ilk sıralarda yer almaktadır. Çünkü yaşandığı toplumda, sahibi olduğu kural kaide ve yasaklar o toplumun kültürünün oluşmasında en birincil amili oluşturmaktadır. Hatta tarihsel süreç içerisinde toplumun yönetim şekli bile dini kurallar çerçevesinde şekillenmiştir. Türkiye Cumhuriyeti'nin mirasını devralıp kurulduğu Osmanlı Devleti'nin yönetim anlayışında da bu durum görülmektedir. Cumhuriyetin ilanından sonra toplumun aydın kesiminden uzman görüşleri alınarak yapılan yenilik çalışmaları içerisinde bütün alanlarda olduğu gibi din alanında da birtakım düzenlemelere gidilmiştir. Bu çalışmamızda Türkiye'nin bilim öncülerinden Prof. Dr. Fuat Sezgin'in din alanında öngördüğü iyileştirme çalışmaları arşiv belgeleri ışığında ele alınacaktır.

\section{Giriş}

Kültür, milletlerin hayat tarzlarının bütününü ifade eden bir kavramdır. Oluşumunda insan yaşantısının içerisinde yeri olan her husus rol oynar. Bu hususların içerisinde din, önemli ölçüde belirleyici bir etkendir. Zira din sadece insan-yaratıcı arasındaki ilişkiyi belirlemekten ziyade yaşam şeklini, toplumsal ilişkileri hatta devletlerde yönetim şeklini dahi belirlemeye varıncaya değin kural kaideler getirmektedir. Bu sebeple din, kültürler için en belirleyici husus olmaktadır. Kültürü kendi kuralları içerisinde tasarlayan din, aynı zamanda o toplum içerisinde yaşama imkânı da elde etmektedir (Tanrıverdi, 2018, s.596). Türklerde din konusu diğer milletlere kıyasla daha önemli bir pozisyondadır. Tarihte kurulan ilk Türk devletlerinden başlamak üzere İslamiyet'i kabul edene kadar devlet yönetme yetkisi Türk yöneticilerine yaratıcı tarafindan verildiğine inanılmıştır (Uğurlu, 2012, s.331). Yaratıcının bu yetkiyi verdiği kişi belirli erdemlere sahip olmalıdır. Hükümdarlığı yapabilmesi için bu özelliklerinden

\footnotetext{
* Sorumlu yazar/Corresponding author.

e-posta: mehmetozalper65@hotmail.com
} 
faydalanması gerekmektedir. $\mathrm{Bu}$ özelliklere sahip biri adalet ve hoşgörü gibi kavramları üst düzeyde kullanmalıdır (Başer, 1990, s.60). Türk devletleri Karahanlılar'dan başlamak üzere İslamiyet'i kabul ettikten (Saltuk Buğra Han 904-911) sonra da din, kurulan devletlerin yönetiminde de belirleyici bir konumda olmuştur (Kafesoğlu, 1998, s.148). Bu dönemden başlamak kaydıyla tarihsel süreçte kademeli olarak oluşan "Türk-İslâm Devlet Geleneği” ile kurulan devletler dünya siyasi tarihinde çok ciddi roller üstlenmişlerdir. İslâm dininin Türk devletlerinin merkezine yerleşmesi Türk Milleti açısından, birliktelik ruhunun gelişmesini, Türk Kültürü'nün temel taşlarından olan "Cihangirlik" anlayışının "Cihat" anlayışına dönüşerek sınırlarının geniş bir coğrafyaya yayılmasını ve dünya tarihinde medeniyet kuran milletler arasında kalmalarını sağlamıştır. Aynı zamanda İslâm dinide Türk Milleti sayesinde bir canlanma yaşamıştır. Türkler İslamiyet'i milli bir din haline getirmek suretiyle on birinci yüzyıldan itibaren İslâm dünyasının bütün dünyadaki yegâne savunucusu haline gelmişlerdir. $\mathrm{Bu}$ sayede de sahip olduklarını erdemleri gün yüzüne çıkartmışlar ve dünya tarihindeki yerlerini tam manası ile bulmuşlardır (Güngör, 1996, s.68-69).

Türklerin İslamiyet'e geçişleri ile birlikte yaşanan en önemli gelişmelerden bir tanesi de göçebe yaşam tarzından yerleşik yaşam tarzına geçiş olmuştur. Yaşam şeklinin değişiminden dolayı doğal olarak sosyal hayatın içerisine de bir takım toplumsal düzenlemeler gelmiştir. Çünkü dinin kendi içerisinde olan birtakım yasaklamalar toplumun tamamında bir düzenleme ve değişim yaşanmasını beraberinde getirmiştir. $\mathrm{Bu}$ değișiklik siyasi manada da kendisini göstermiştir. $\mathrm{Bu}$ dönemde İslamiyet öncesinde olduğu gibi milletin yöneticiye olan bağlılığ devam etmiş ve dayandırılan nokta "Allah'ın nasip ettiği" yönetici şeklinde olmuștur. Yönetimin usulleri noktasında da töre hukukunun yanına İslâm hukuku eklenmiştir. İki hukukunda içerik olarak benzerliklere sahip olması bir çatışma yaşanmadan yürütülmelerini sağlamıştır. İslâm öncesi dönemde olan "toy" meclisi İslamiyet'ten sonra "şura-meşveret" şekline dönüşmüş içerik bakımından aynı amaca yönelik oldukları için yönetimsel olarak da toplumsal olarak da bir çatışma yaşanmamıştır. Misyon olarak her iki kurumunda görevi siyasi gücün keyfi uygulamalarının önüne geçmek ve bu kurumu denetlemektir. Burada önemli olan husus din faktörünün yönetim alanı başta olmak üzere her noktada toplumun içine dahil olmasıdır (Coşkun, 2016, s.130).

İslâmiyet kabul edilmesinden sonra din, kurulan bütün Türk devletlerinde merkezde yer almıştır. Yakın tarih içerisinde Osmanlı Devleti'ne baktığımız zaman din, toplumda en önemli değer yargısı konumundadır. Bunun yanı sıra yönetim nezdinde de çok önemli bir meşruiyet aracı ve güç haline gelmiştir. Devletin ilk kuruluş dönemlerinde Osmanlı Devleti'nin yöneticileri aslında kendilerinden önceki devletlerde olan sistemden farklı yeni bir sistem getirmemişleridir. Anadolu'ya yerleşmiş olan Müslüman Türkler'in sahip olduğu sistemi uygulamışlardır. Dinin uzun bir zaman zarfında şekillendirmiş olduğu örf, adet, hukuk, ahlâk ve ekonomi gibi sistemlerin aynısını alıp uygulamışlardır. Türk Kültürünün özünde olan "MilletDevlet" anlayışına ek olarak Osmanlı Devleti'nde "DinDevlet" şeklinde bir anlayış eklenmiştir. Devlette hâkim olan din merkezli bu anlayıș toplumun içerisine de yansımış ve yaşantının hemen hemen yegâne düzenleyicisi din faktörü olmuştur. Osmanlı Devleti'nin büyük bir dünya devleti olmasına giden yolda İslâm'ın bu düzenlemelerinin ve hoşgörüsünün önemli bir etki yaptığı söylenebilir (Baş, 2011, s.82). Osmanlı Devleti'nde idareciler yapmış oldukları bütün faaliyetlerde dine uygun olmayı ön plana almışlardır. İslâmiyet artık toplumun kimliği haline gelmiştir. Tıpkı yönetimde olduğu gibi toplumun ekonomik ve sosyal yapısı dini kurallar çerçevesinde şekillenmiştir. Diğer Türk İslâm devletlerinden kısmen farklı olarak Osmanlı Devleti'nde halkın eğitilmesinde de din merkezde olmuştur. Devlet bürokrasisinde önemli makam olan "Şeyhülislâmlık" makamının kontrolünde camilerden başlamak üzere halkın dini vecibeler ile eğitilmesine çalışılmıştır. Buna bağlı olarak toplum yaşantısında tıpkı yönetimde olduğu gibi din en belirleyici unsur olmuştur (Bulut, 1999, s.115).

Yapılan birçok değerlendirmede Osmanlı Devleti'nin tam bir şeriat devleti olarak değerlendiği görülmektedir. Bu değerlendirmenin temelinde devletin "gaza" geleneğine ciddi bir önem atfetmesi yatmaktadır. Nitekim Osmanlı Devleti batı dünyasının karşısında olarak İslâm dünyasının yegâne savunucusu konumunda olması bu değerlendirmelerin yapılmasındaki en önemli sebeptir. Klasik bir şeriat devletinin hukuk sisteminde sadece şeri hükümler varken, Osmanlı Devleti'nin hukuk sistemi içerisinde örfi hukuk kuralları da șeri hukuk kuralları kadar önemli olmuştur. Ancak örfi kurallar kültür ile alakalı olduğundan dinin kültürü oluşturan önemli unsur olması, örfi hukuk kurallarının da toplumsal hayatta her alanda olduğu gibi İslâm geleneği ile şekillenmesini beraberinde getirmiştir. Dolayısı ile her iki hukuk kuralları da bir çatışma değil uyum içerisinde yürütülmüştür (Taşbaş, 2018, s.156). Osmanlı Devleti, kuruluş amacı olan İslâmiyet için verdiği mücadeleleri dini hayatı toplum içerisine hâkim kılmak içinde devam ettirmiştir. Halkın dini gereklilikleri bilmesi ve buna uygun yaşaması için eğitim sistemini oluştururken dini eğitimi de ön plana almıştır. Toplumun bu eğitimi alacağı kişileri belirlemek ve bunların yetiştirilmesini sağlamak içinde büyük bir özen göstermiştir. Din adamlarının görevlere atanmalarını ve çalışmalarını belirleyen kriterleri tarihsel süreç içerisinde iyileştirerek bu noktada kalifiye elemanların ortaya çıkmasına gayret etmiştir (Kaya, 2017, 242). Bu gelişmeler neticesinde Osmanlı toplumunda din bir ideoloji halini almış ve maddi-manevi dünyanın esas kaynağını teşkil etmiştir. Din adamları vasıtasıyla topluma aktarılan dini bilgiler hayatın mutlak gerçekliğinin özünü oluşturmuştur. $\mathrm{Bu}$ sistem üzerine bina edilen toplumsal düzende halkın birbirleri ve devlet ile olan ilişkileri dini kuralların özünde var olan hoşgörü temeline dayanmıştır. Devlet bu manevi gücü devamlı surette canlı tutmak için gayret etmiştir (Kodaman, 2007, s.3).

\section{Osmanlı Devleti'nde Dini Yapıda Bozulma ve Türkiye Cumhuriyeti}

Osmanlı Devleti'nde din konusunda esas söz sahibi olan din adamlarının yetiştirildiği medreseler, devletin tarihsel süreçte yükselme ve çöküşüne bağlı olarak paralel bir seyir izlemiştir. Özellikle on altıncı yüzyılın sonlarına doğru ekonomi, idare, adalet gibi mekanizmaların Osmanlı Devleti'nde gerilemeye başlaması ile birlikte dini eğitimde de ciddi bir gerileme yaşanmıştır. Bu gerileme yönetim 
nezdinde hissedildiği ölçüde toplumda da aynı şekilde hissedilmiş ve sosyal dokuda birtakım bozulmalar yaşanmıştır. Bozulmanın başlangıcı olarak medreselerin işlerliğini sağlayan kanunlara riayet edilmemesi, din adamlarının tayinlerinde ve yükselmelerinde rüşvet, büyük alimlerin çocuklarının kayrılması, din adamlarının göreve atanma yeterliliklerini belirleyen şartlarını uygulanmaması hatta din eğitimi almadan din adamı olacak dereceye varıncaya değin atamaların yapılmış olması gibi usulsüzlükler yaşanmıştır (Sarıkaya, 1999, s.24,25). Bu dönemde sadece Osmanlı Devleti’nde değil bütün İslam dünyasında dinin çağa ayak uydurması bakımından sıkıntılı günler yaşanmış dinin temel yapısında bozulmalar baş göstermiştir. Müslüman düşünürler bu bozulmayı düzeltmek için çaba sarf etmişlerdir (İşler, 2018, s.52).

On üçüncü yüzyılda Türk-İslâm kültürünün öncüsü olacak şekilde temellerini atan Osmanlı Devleti, dinin kural ve kaidelerine bağglılı̆̆ ve bunu yönetimde içselleştirmesi sayesinde dünyada üç kıtada hüküm sürmeyi başaran bir dünya devleti haline gelmiş iken, savunuculuğunu üstlendiği İslâm dininin sancağını altı asra yakın bir süre bütün dünyada dalgalanmıştır. Sahibi olduğu dini hoşgörü sayesinde hakimiyet kurduğu bölgelerin halkları tarafindan benimsenmiştir. Ama on dokuzunca yüzyıla gelindiği zaman yukarıda bahsi geçen bu bozulmalar sadece dinde sınırlı kalmamıştır. Osmanlı Devleti'nin bu denli yükselmesinde çok önemli etkileri olan din gibi diğer bütün sistemlerde (eğitim, adalet, yönetim) çok ciddi bozulmalar yaşanmıştır. Çünkü bu sistemlerin esas ilham kaynağı dindi. Toplumsal hayatta yaşanan dini çöküntü bu sistemlerinde her birinin çökmesini beraberinde getirmiştir. Aynı dönemde dünyada da bir takım önemli siyasi olaylar cereyan etmekteydi. Bunlardan Osmanlı Devleti'nin yıkılma sebebi olan Birinci Dünya Savaşı'na İtilaf devletleri safında giren Osmanlı Devleti’nin siyasi varlığ son bulmuştur (Rogan, 2017, s.18).

Osmanlı Devleti'nin son bulmasindan sonra onun tarihi bakiyesini devralarak kurulan Türkiye Cumhuriyeti, bilinen Türk-İ̀lâm hakimiyet telakkisinin kısmen dışına çıkmıştır. Osmanlı Devleti'nden farklı olarak meşruluğunu ve iktidar gücünü dine dayandırmamıştır. Dönemin şartları da göz önüne alınarak değerlendiği zaman özellikle Osmanlı Devleti'nin dini kurum ve makamlarında yaşanan bozulmalar bu değişimin yaşanmasında kısmen etkili olduğu söylenebilir. Elbette ki küresel ölçekte dünyada yaşanan değişim ve dönüşümler, etkisini yitiren fikir akımları ve bunların yerine önem kazanan yeni fikir akımlarının ortaya çıkması, çok uluslu devletlerin yıkılıp yerine ulus devletlerin kurulması çok önemli etkiler yapmıştır. 29 Ekim 1923 'te Cumhuriyet'in ilan edilmesi ile yeni devletin temellerinin dayandığ 1 ilk mercinin halk olduğu tasdiklenmiştir (Tayhani, 2009, s.522).

Devlet yönetiminde en önemli güç merkezi olan din, hayatın içerisinde kalmak kaydıyla yönetimdeki etkisi azaltılmıştır. Devletin başkanı dini kuralların uygulanmasında ve anlatılmasında en üst derecede yetkili konuda iken bu görev 3 Mart 1924 tarih ve 429 sayll karar ile kurulan Diyanet İşleri Reisliği'ne verilmiştir. Çıkartılan kanunla dini idare eden Şer'iye ve Efkaf Vekâleti kaldırılmış onun yerini alacak kurumlar normal bir idari yapıya dönüşmüştür. Dinin toplumsal yaşantıdaki yeri korunmak suretiyle özü dünyevi bir niteliğe bürünmüştür
(BCA Başbakanlık Cumhuriyet Arşivi, 51-0-0-0-2-11-34, Aydın, 2019, s. 892). Yeni kurulan Diyanet İşleri Reisliğinin başkanlığına da aynı yıl Rıfat Börekçi'nin ataması yapılmıştır (BCA 51-0-0-0-2-12-2). Osmanlı Devleti'nde Şeyhülislam'lı makamında olan bu görev Türkiye Cumhuriyeti'ndeki yeni kuruma göre çok daha geniş yetkilere sahipti. Sadece dini konularda fetva vermekle sınırlı olmayan bu görevde devletin yönetimiyle ilgili konularda birinci derece de söz sahibiydi. Bunların yanında yargı ve eğitim konularının yürütülmesi de bu makama bağlıydı. Diyanet İşleri Başkanlığı ise bu görev ve yetkileri Cumhuriyet'in kurulması ile birlikte Milli Eğitim Bakanlı, Adalet Bakanlığ gibi kurumlara devretmişti. Diyanet İşleri Başkanlığı ise 14 Haziran 19352800 sayılı kanun ile ilk teşkilat yönetmeliğini çıkartmış ve din konulu kamu hizmetleri, ibadethanelerin temini, temizliği, din görevlilerini atamalarını yapan bir kurum olarak günümüzde de varlığını devam ettirmektedir (Yücel, 1999, s.458).

Cumhuriyet'in kuruluş ilkelerinden olan laiklik ilkesi çerçevesinde yapılan bu düzenlemeler yönetimsel olarak kısmen ileri bir aşama olmasına karşın toplum nezdinde istenilen sonucu tam olarak vermemiştir. Toplumun yukarıda özetlendiği üzere tarihsel ve kültürel değerler bakımından dinle çok sıkı bir ilişkisinin olması burada ki en temel etken olarak kabul edilebilir. Bunun yanı sira özellikle modernleşme bağlamı içerisinde sanayi toplumu olarak adlandırılabilen yeni toplum düzeninde insana bağlı olarak ortaya çıkan bir takım önemli sorunlar da baş göstermiştir. Toplumda yaşanan bu soysal problemler sosyal yaşamda çok ciddi sarsıntılara yol açmıştır. Tarihsel süreç içerisinde örnekleri görülebilen bu tarz sorunlara çözüm getiren geleneksel din anlayışı bu dönemde aynı sorunları çözmede kısmen etkisiz kalmıştır (Çelik, 2018, s.217).

Bilinen bir gerçeklik şudur ki din, misyon olarak yaşandığ 1 topluma zihniyet kazandırma ve yeni sosyal düzenlere karşı vizyon geliştirme gibi bir etkisi vardır. Bunun yanında din, öz meseleleri hariç olmak üzere toplumsal olan bütün konularda mutlaka bir hüküm getirme ve dünyevi sorunların çözümüne dair bir kaynak olma özelliği taşır. Öz itibarı ile şu denilebilir ki; din hayatta karşılaşılabilecek her türlü soruna karşı toplumun takınması gereken tutum ve davranışları belirleyen bir içeriğe sahiptir. Bireyler mensup oldukları dinin öngördüğü ölçüde dünya bakışları şekillenir. Belirli bir zaman aralığında yaşanması ile birlikte dinin șekillendirdiği kültür neticesinde toplumda bireylerin birbirleri ile münasebetlerinde ve yaşanan sosyal olayların çözümünde din çok etkili konumda yer alır (Keskin, 2004, s.16). Türkiye Cumhuriyeti'nin kuruluşunda dinin bu özelliklerinin geçmiş uygulamalarda su istimallere uğradığı, halkın dine olan bağglılığ kullanılarak yanlış yönlendirmeler içerisine sokulduğu, kişilerin din adamına olan güveni kullanarak şahsi menfaat elde etmek için uğraşması gibi sorunlar tecrübe edilmiștir. Diyanet İșleri Başkanlığı kısmen de bu amaç için kurulmuştur. Ancak Cumhuriyet Tarihi içerisinde var olan uygulamalarda, devletin yeni kurulmuş olması sebebiyle imkanların kısıtlı olması s1kı bir denetim yapılamamasına sebebiyet vermiş bu noktada dini ve toplumsal alanlarda esas faydalı olan kişi ve kurumlarda bu yeni uygulamalardan etkilenmişlerdir. Diyanet İşleri Başkanlığı, tarihi ve kültürel bir geçmişi olmadığı için 
bunların tasfiyesinin oluşturduğu boşluğu tam manası ile dolduramamıştır.

\section{Fuat Sezgin ve Din Alanında Hazırladığı Rapor}

Türkiye Cumhuriyeti yapmış olduğu inkılaplar noktasında dünyadaki diğer rejim değişikliklerinden farklılık arz etmektedir. Dünyadaki hemen hemen bütün inkılaplar seyir olarak tabandan tavana doğru gelişirken Türk İnkılabında durum farklılık arz etmiştir. Tavandan tabana doğru başlayan Türk inkılabının temsilci kadrosu da devlette üst düzey asker ve bürokratlardan oluşmuştur. Türk İnkılabının öngördüğü değişiklik rejimden başlamak üzere çok köklü olarak eski rejimin bütün kurumlarına yönelik yapılmıştır. Doğal olarak eski rejime ait olan bütün organizasyonların revize edilmekten ziyade tamamen ortadan kaldırılıp yerine yenisinin getirilmesi gerekmekteydi. Ancak bu yeni kurumların ve yeniliklerin tarihsel süreçte bir karşılığ olmadığı için toplum ve halk ile bütünleşmesi bir hayli güç olmuştur. $\mathrm{Bu}$ yeniliklerin genel anlamda batının örnek alınması şeklinde olması yönetici kadronun uygulamalarda sıkıntılarla karşılaşmasını beraberinde getirmiştir. Türk toplumunda batılı değerleri günlük yaşantıya uygulamanın tecrübeleri vardı. Ancak inkılaplar ile bu değerleri bize ait olan değerlerle bütünleştirip yeni bir formda uygulamayı hedeflemekteydi. Yapılacak olan bu uygulamada hem çok zorlu hem de geniş bir zaman dilimine yayılmaya mecbur olmuştur (Eraslan, 2002, s.143).

Türkiye Cumhuriyeti batı kaynaklı modernleşmeye ciddi bir önem vermiştir. Dış politika olarak yüzünü batıya dönen bir devlet olmuştur. $\mathrm{Bu}$ sebeple uygulama sahasina koyduğu batıdan transfer yolu ile aldığ 1 yenilikleri tam manası ile anlamak ve doğru bir șekilde uygulamak amacı ile uygulamak üzere sıklıkla batıdan konunun uzmanlarını ülkeye getirmek suretiyle bazen de yazılı olarak bu uzmanlardan görüș talep etmiștir (Baylı, 2013, s.49).

Toplumsal yeniliklerin içselleştirilmesi ve halk tarafindan kabul edilmesi bütün ülkelerde ciddi sancilar ile beraber olmuştur. Türk inkılabının da toplum tarafindan benimsenmesi çok uzun bir sürece yayılmıştır. Özellikle rejim şekli konusunda muhalif olan bir kesimin var olduğu bilinmektedir. Daha spesifik konularda da yeniliklerin karşısında yükselen bir ses muhakkak olmuştur. Bu karşıtlıkların bazen bir isyan ile ortaya çıktığı zamanlarda yaşanmıştır. Olayların arttığı bu dönemlerde Türkiye Cumhuriyeti tarihinde ordunun duruma müdahaleleri de birkaç kere müşahede edilmiştir. 27 Mayıs 1960 askeri darbesi de bunlardan bir tanesidir. Devlet ve ona bağlı olan kurumların bu olayların önüne geçmek için belli başlı girişimleri olmuştur. Burada zaman zaman gerek yenilikler çerçevesinde kurulan yeni kurumların işlerliğinin arttırılması, gerekse de bu kurumların halk nezdinde benimsenmesini sağlamak amacı ile yurtiçinden uzman görüşleri alınmış ve uygulanmaya çalışılmıştır.

1960 darbesine doğru giden yıllarda ülke de asayiş olaylarında ciddi bir artış yaşanmıştır (BCA 30-1-0-0-67418-1, BCA 30-1-0-0-67-423-7). Yukarıda anlatıldığı üzere dinin toplumsal düzeni sağlamada olan yüksek etkisine binaen Diyanet İşleri Başkanlığı, kendi yapısında bir değişiklik yapmak ve tavsiyelerini almak üzere Türkiye'nin bilim öncüleri arasında ilk sıralarda yer alan ve o tarihlerde Doçent unvanı ile İstanbul Üniversitesi'nde görev yapan Prof. Dr. Fuat Sezgin'den din ve din adamlarının eğitimleri ve misyonları hakkında görüşlerini bildirmesini isteyen, 6 Ağustos 1957 tarih ve 12/17321 sayılı bir yazı yazmıştır (BCA 30-1-0-0-105-657-8-9-1) .

Türkiye'de yetişen ender bilim adamlarından olan Fuat Sezgin 24 Ekim 1924 tarihinde Bitlis'te doğmuştur. Erzurum'da orta öğretim ve lise eğitimini tamamlamış ve ideali olan matematik okumak ve mühendis olmak için 1947 yılında İstanbul'a gitmiştir. Ancak orada bir konferans vesilesiyle tanıştığı Alman kökenli şark uzmanı Helmut Ritter'den çok etkilenmiş ve onunla çalışmaya karar vermiştir. İkinci Dünya Savaşı'nın devam ettiği o yıllarda Türkiye'de eğitimin askıya alınması ile beraber hocasının yönlendirmeleri ile Arapça'yı ileri düzeyde öğrenmiştir. Doktora tezinde de Arapça üzerine çalışmalar yapan Sezgin, 27 Mayıs 1960 askeri darbesinden sonra yurtdışına çıkmak zorunda kalmıştır. Çalışmalarını Franfurt Üniversitesinde devam ettiren Sezgin, İslâm bilimleri üzerine yoğunlaştırmıştır. 1965 yılında Franfurt Üniversitesi Instıtut für Geschichte der Naturwissenschaften'da ikinci doktara tezini Cabir İbn Hayyan üzerine yapmış ve 1966 yılında profesör unvanını kazanmıştır. Bütün hayatını İslâm bilimleri tarihi üzerine çalışmalar yaparak geçiren değerli bilim adamının bildiği yabancı dil sayısı ve günlük çalışma saatlerinin 17 saate kadar çıkması neticesinde bilimin esas kökeninin ve kaynağının bilinenin aksine Batı medeniyeti olmadığını ve İslâm medeniyetinin ve Müslüman bilim adamlarının bilime ne denli önem verdiğini kanıtlamaya harcamıştır. Dünyanın dört bir tarafindan büyük zorluklara katlanarak topladığı 45.000 cilt kitap ve 10.000 adet mikrofilme ulaşan bir kütüphane kurmuştur. Yaşamı boyunca dünyanın en seçkin eğitim kurumlarından ve ülkemizden sayısız ödül ve unvanlara layık görülen Fuat Sezgin, 30 Haziran 2018'de İstanbul'da vefat etmiştir Sezgin, 2017, s.8).

İstanbul Üniversitesi’nde Doçent olarak görev yaptığı 1957 yılında Diyanet İşleri Başkanlığı'nın kendisinin İslâm ile derin bilgisine binaen hazırlamasını istediği raporda Fuat Sezgin, din konusunda en yetkili kurum olan Diyanet İşlerinin teşkilatı için öngördüğü düzenlemeler ve alınması gereken tedbirlerden bahsetmiş ve din görevlileri olan müftü ve vaizlerin toplum hayatındaki fonksiyonlarına değinmiştir. Diyanet İşleri Başkanlığı'nın kendi yönetmeliğinde, İslam dininin inanma ve ibadet alanıla ilgili bütün hüküm ve işlemleri yürütmek ve yönetmekle görevli tek yetkili kurum olarak kendisini tarif etmesine rağmen kurulduğu günden itibaren bünyesinde birçok kadro tahsis edilmişse de sahibi olduğu misyon bakımından çok durağan bir seyir izlediğini vurgulamıştır. 1924 yılında devleti kuran kadroların acele bir şekilde aldığı tedbirler içerisinde ve derinlemesine bir araştırma dahi yapmadan kurulan bu kurumun aradan otuz yıl geçmesine rağmen bünyesinde ciddi bir değişiklik yapılmadığını söylemiştir. Yaşanılan toplumda din müessesesinin toplum için önemli ve gerekli bir müessese mi? yoksa zararlı bir müessese mi? olduğu şeklinde bir sorunun sorulması gibi sosyal bir problem nasıl analiz edilip cevap verilmemiş ise Diyanet İşleri Teşkilatının kapsam ve önemi üzerinde de ayını şekilde ciddiyetle durulmadığını belirtmiştir. Diyanet İşlerinin kuruluşundan bu yana geçen otuz üç yıl içerisinde cansız bir şekilde herhangi bir ilerleme kaydetmemesinin bu alanda çok ciddi boşluk oluştuğunu ve ülkedeki dini sorunların sosyal bir çerçeveden ele alınmasını gerekli kıldığını belirten Fuat Sezgin, din müessesinin, ülkedeki 
maddi ve manevi ilerlemenin gerçekleşmesi için çok önemli bir misyonu olduğunu belirtmiştir (BCA 30-1-0-0-105-6578-9-4).

Fuat Sezgin'e göre dinin bu önemli etkisi toplum nezdinde muhakkak olumlu bir dönüşüm yaşayabilme imkanına sahiptir. Bunu başarabilmenin öncelikli şartının da alanına hâkim bilgi ve becerilerle donatılmış din adamları olduğunu belirtmiştir. İnkılapların toplum tarafindan benimsenip uygulanmasını sağlamak ve toplum için zararlı olan bütün konuları bertaraf etmek için dini bilgilerin kullanılmasının olumlu sonuçlar doğuracağını belirtmiştir. Günümüzde hem toplum hem de bireyler için en fazla fayda sağlayacak unsurun din olduğunu ve bunun kanıtının da Türk milletinin tarihi olduğunu burada içerisinde bulunulan zorlu günleri atlatmada dinin ne denli büyük etkiler uyandırdığının örneklerinin mevcut olduğunu vurgulamıştır. Diyanet İşleri'nin ortada olan bu gerçekliliğe rağmen herhangi bir faaliyete girişmemesinin anlamsız olduğunu, başkanlık bünyesinde görevli din adamlarının özellikle müftü ve vaizlerden alışılmışın dışında hareket eden şahısların bulunduğunu ve bunların faaliyetlerinde çok olumlu dönütler almalarına rağmen ne başkanlık bünyesinde ne de gerekli diğer mercilerde gereken etkiyi uyandırmadığını ve örnek alınmadığını söylemiştir. Sezgin'in inandığı en önemli husus; gerektiği ölçüde faydalanıldığı takdirde müftü ve vaizlerin devletin eğitim öğretim noktasında yükünü en az yarı yarıya düşüreceği, okuma yazmanın yaygınlaştırılması meselesinin halledileceği bunun yanında toplumdaki diğer sorunlardan olan gümrük ve orman kaçakçılığı, diğer asayiş olaylarının tamamen biteceğidir. $\mathrm{Bu}$ görevi yapacak olan müftü ve vaizlerin Diyanet İşleri'nin mevcut nizam programından çıkarılmak suretiyle eğitilmeleri ve gerekli teknik donanımın sağlanması gerekmektedir. Bu yapılacak işlem toplumu olumlu yönde ve çok derinden etkileyeceği için özünde çok ciddi bir yatırım olarak görülmesi gerekmektedir. Elbette ki bu görevlilerin kendi imkanları ile bu işi başarabilmeleri mümkün olmadığı için bu işi üstlenecek merkezi bir sistemin kurulmasının zaruri olduğunu beyan etmiştir. Bunun da Diyanet İşleri'nin kendi bünyesinde bir "Manevi Kalkınma Bürosu" veya Toplu Çalışma Bürosu” ismi ile kurulmasının şart olduğunu belirtmiştir (BCA 30-1-0-0105-657-8-9-5).

Fuat Sezgin, kurulmasını öngördüğü büronun Diyanet İşleri Reisliği'nin bünyesinde modern bir formasyona sahip olmasını, alanında uzman olan kişilerden ve özellikle üniversitede görevli akademisyenlerin dahil olacağı bir kadroya sahip olması gerektiğini belirtmiştir. Oluşan komisyonun iki tane önemli görevinin olmasından bahseden Sezgin, bu görevleri şöyle sıralamıştır; Müftü ve vaizlere yönelik olarak belirli bir eğitim programı hazırlamak ve onların vatandaşları, belirli ve sınırları oluşturulmuş bir hedefe yönlendirilmelerini sağlamak. Vatandaşa gelişi güzel ve toplumun temellerini sarsacak derecede yanlış bilgiler vermemelerini telkin etmek. Eğitim alan din görevlilerini klasik bilgi ve kitapların dışına çıkartmak suretiyle orijinal kitaplar okumalarını sağlamak, İslâm ilminin tarihi seyrinden haberdar olmalarını sağlayarak kendilerini çağın gerekliliklerine uygun din adamları haline gelmeleri noktasında telkin etmek. Bu iki hedeften ikincisinin başarılabilmesi için bu konuları içeren kitap ve telif eserleri tercüme ettirmek, ödül ve yarışmalar düzenleyerek bu kitapları hazırlatmak bu kitapların baskısını yaptırdıktan sonra müftü ve vaizlerden bu kitapların anlamlı ve kısa özetlerini çıkartmaları istemek, çıkartılan bu özetlerin Diyanet İşleri'nde görevli personel tarafindan değerlendirilmesini istemek ve sonuçları bildirmelerini sağlamak gerektiğini belirten Sezgin bu vesile ile bütün din görevlilerin sürekli bir öğrenme süreci yaşamalarını ve bu bilgilerinde halka aktarımının sağlanacağını belirtmiştir. $\mathrm{Bu}$ amaçların gerçeğe dönüşebilmesi için özelliklere müftülük makamının şekil ve içerik olarak bir değişime ihtiyacı olduğunu belirten Fuat Sezgin, birçok kasabada müftünün evinden hizmet vermesini yanlış bulmakta müftülerinde diğer devlet memurları gibi bir bürolarının olması gerektiğini, direk toplumun önünde olmalarını ve sahibi oldukları büroda bir kütüphanenin kurulmasını ve halkın bu kütüphanelerde aktif bir şekilde dahil olmalarının önemli olduğunu vurgulamıştır (BCA 30-1-0-0-105-657-8-9-6).

Yeni yetişen neslin şekil konusunda hassas olduğunu belirten Fuat Sezgin müftülük makamının cezbedici bir hale dönüşmesinin şart olduğunu belirterek, İstanbul gibi İslâm dininin sembollerinden olan bir şehrin müftülük makamının raporun yazıldığı günlerdeki kötü manzarasına bakılarak esas sorunun toplumun en büyük sosyal meselelerinden olan İslam dininde aranmasının devam edeceğini söylemiştir. Diyanet İşlerinde görevli personelde kurulacak bir ekibin seyyar bir şekilde ülkedeki köy ve kasabaları dolaşmak sureti ile din hakkında belli başlı elzem bilgileri coşkun bir şevk ile halka aktarmaları gerektiğini vurgulayan Fuat Sezgin, bu ekibinin teknolojinin imkanlarından hat safhada faydalanarak önemli vaazları, nasihatleri ve mevlitleri ses kayıt cihazları ve hoparlörler vasıtasıyla halka sık sık dinleterek dini, mabetlerin dışına taşımalarını tavsiye etmiştir. $\mathrm{Bu}$ tavsiyelerin genel olarak toplum nezdinde çok faydalı olacağını belirten Fuat Sezgin Diyanet İşleri Reisliği'nin bünyesinde bu heyecanı taşıyan görevlilere bu görevi vererek ülke genelinde uygulamalarını tavsiye etmiştir. Alınacak sonuçların muhakkak ki okuma yazma oranında artış, muhtelif asayiş olayları ve suçlarda azalma, halkın hayır işlerinde katılımın artması, orman yangınları, gümrük kaçakçılığı gibi toplumsal birçok sıkıntının istatiksel olarak düşeceğini önemle vurgulamıştır (BCA 30-1-0-0-105-657-8-9-7).

Prof. Dr. Fuat Sezgin'in hazırlamış olduğu rapor ile alakalı görüş bildirilmesi istenen dönemin Başvekâlet Mütehassis Müşavirliği, 8 Ağustos 1957 tarih ve 108 sayı numaralı bir yazı ile rapordaki görüşlerin son derece yerinde olduğunu, elbette ki din adamlarının dinin içtimai meseleleri noktasında halkı bilgilendirmede birinci derece görevli olduklarını belirtmiştir. Raporda bahsi geçen büronun biran evvel kurularak müftü ve vaizlerin bahsi geçen telif ve tercüme eserleri okumalarının şart olduğunu, tavsiye olunan önerilerin ne dine ne de rejime bir karşıtlığının olmadığı belirtilerek yasal mevzuat çerçevesinde herhangi fazladan işleme gerek kalmadan bir an evvel uygulanmasının çok yerinde olacağ yazılmıştır (BCA 30-1-0-0-105-657-8-9-1, BCA 30-1-0-0-105-657-8-9-2).

\section{Sonuç}

Toplumların ilerlemesi ve gelişmesi noktasında gayretli insan faktörü son derece önemlidir. Bireyleri dahil oldukları toplumda genel bir kültürel özellik olarak gayretli ve dürüst olmaları da bu gelişmeyi sağlayan en önemli husustur. 
Kültürü oluşturan öğeler arasında din faktörünün etkisi diğer faktörlere göre bir hayli fazladır. Nitekim Türk-İslam tarihi içerisinde iz bırakmış ve dünya siyasi tarihinde rol oynayan Türk devletlerinin dini aydınlanma ile birçok zorlu dönemler geçirdikleri bilinmektedir. Türkiye Cumhuriyeti'nin kuruluşu ile birlikte oluşturulan yeni kurumlar tarihi ve kültürel bir altyapıya sahip olmadıkları için gelişim aşamasında birtakım sıkıntılar ile karşılaşmışlardır. Diyanet İşleri Reisliği'de bu kurumlardan biridir. Elbette ki kuruluş aşamasında birtakım sıkıntılar yaşamıştır. Cumhuriyet'in diğer kurumlarında olduğu gibi bu kurumda da sistemi tam anlamı ile oturtabilmek için uzman isimlerden öneriler istenmiştir. Prof. Dr. Fuat Sezgin gibi İslâm Tarihi ve İslam Bilim Tarihi konusunda çok önemli bir isim olan, bütün dünya tarafindan kabul edilen müstesna bir şahsin bu kuruma görüşlerini bildirdiği rapor bir anlamda İslam dinin tam manası ile toplum hayatına dahil edilmesinin gerekliliğini vurgulamıştır. Türk-İslam tarihinin bu uygulamayı gerçekleştirerek altın çağlar yaşandığı birçok örneğin olduğunu bizzat bilen Fuat Sezgin, toplumsal olayların asayişsizliğin insanlardaki kanaat ve iman duygusunun gelişmesi ve dine olan bağl1lığın arttırılarak din adamlarına olan inancın yükselmesine bağlı olduğunu belirtmiştir. Bunu sağlayabilmenin en önemli adımının ise din kurumlarının ve din adamlarının mensubu oldukları dini doğru anlayarak onun kural ve kaideleri içerisinde kendilerini geliştirmeleri gerektiği noktasında olduğunu belirtmiştir.

Nitekim kendisine bu raporu yazma görevinin verildiği tarihe bakıldığı zaman Türkiye Cumhuriyet Tarihi'nin en önemli olaylarından olan 27 Mayıs 1960 askeri darbesinin hemen öncesinde olduğu görülmektedir. $\mathrm{Bu}$ dönemde Türkiye iç huzursuzluk ortamının seviye olarak çok üst düzeyde sıkıntılarını yaşamıştır. Muhtemelen bu sıkıntıların giderilebilmesinin en önemli yolu olarak görülen toplumun dine bağlılığını arttırılmasın çareleri aranırken kıymetli bilim adamına bu görev verilmiştir. Yazdığı raporda Türk tarihine, dinine, ülke rejimine yarar sağlayacak ve toplumu ileriye taşıyacak çok önemli tavsiyelerde bulunmuştur. 1960'da gerçekleşen askeri darbede Fuat Sezgin gibi çok değerli bir bilim adamına üniversiteden el çektirmiş görevine son verilmiştir. Çareyi yurtdışına çıkmakta bulan bilim adamı orada çok ciddi çalışmalara imza atmıştır. Türkiye Cumhuriyeti'nin tarihine de hiçbir ciddi gerekçe gösterilmeden çıkartılan bir kanunla, bütün dünyada sayısız ödüllere layık görülen kıymetli bir bilim adamının ülke dışına çıkmasının kaybı işlenmiştir.

\section{Kaynakça}

Cumhuriyet Arşivleri Başkanlığı.

Aydın, Ö. (2019), Diyanet İşleri Başkanlığı Üzerine Bir Tartışma: Temsil Meselesi, Atatürk Üniversitesi Iktisadi ve İdari Bilimler Fakültesi Dergisi, 33(3), 891-918.

Baş, E. (2011), Osmanlı Devleti’nin Kuruluş Döneminde Din Kültürü ve Hayatı (Tarih Yazarı Neşri'nin Anlatılarına Göre), Ankara Üniversitesi Ilahiyat Fakültesi Dergisi, 52(2), 55-84.

Başer, S. (1990), Kutatgu Bilig'de Kut ve Töre, Kültür Bakanlığı Yayınları, Ankara.
Baylı, G. (2013), Türkiye'de İstihdam Edilen Fransız Uzmanlar ve Türk Modernleşmesine Katklları, Hacettepe Üniversitesi Atatürk İlkeleri ve İnkılap Tarihi Enstitüsü Yayınlanmamış Yüksek Lisans Tezi, Ankara.

Bulut, M. (1999), Osmanlı Devleti'nde Dini Teşkilatlanma ve Yaygın Din Eğitimi, Diyanet İlmi Dergi, 35(2), 101-116.

Coşkun, Ö. (2016), Türk Yönetim Sistemi Üzerine Kısa Bir Değerlendirme, The Journal of International Lingual, Social and Educational Sciences, 2(2), 126135.

Çelik, C. (2018), Türkiye'de Dini Hayatın Sosyo-Tarihsel Boyutları ve Dindarlığın Dönüşen Görünümleri (1960-1980) Bilimname Dergisi, 25(1), 215-249.

Eraslan, C. (2002), Türk İnkılabında Yöntem ve Anlayış, Yakın Dönem Türkiye Araştırmaları Dergisi, 2, 129162.

Güngör, E. (1996), Tarihte Türkler, Ötüken Yayınları, İstanbul.

İşler, A. (2018), Demokrat Parti Döneminde Dinde Reform Tartışmaları, Íçtimaiyat Dergisi, 2(2), 52-64.

Kafesoğlu, İ. (1998), Türk Milli Kültürü, Ötüken Yayınları, İstanbul.

Kaya, U. (2017), Osmanlı'da Din Hizmeti Görevlilerinin Atanma ve Çalışma Şartlarını Düzenleyen Tevcîh-i Cihât Nizâmnâmeleri Hakkında Bir Değerlendirme, Cumhuriyet Ilahiyat Dergisi, 21(1), 203-254.

Keskin, M. (2004), Din ve Toplum İlişkileri Üzerine Bir Genelleme, Din Bilimleri Akademik Araştırma Dergisi, 4(2), 7-21.

Kodaman, B. (2007), Osmanlı Devleti’nin Yükseliș ve Çöküş Sebeplerine Genel Bir Bakış, Süleyman Demirel Üniversitesi Fen-Edebiyat Fakültesi Sosyal Bilimler Dergisi, 16, 1-24.

Rogan, E. (2017), Osmanlı'nın Çöküşü Ortadoğu'da Büyük Savaş (1914-1920), İletişím Yayınları, İstanbul.

Sarıkaya, Y. (1999), Osmanlı Medreselerinin Gerileme Meselesi: Eleştirel Bir Değerlendirme Meselesi, İslâmi Araştırmalar Dergisi, 3, 23-39.

Sezgin, F. (2017), Íslam Bilimler Tarihi Konferanslarl, 1, İslam Bilim Tarihi Araştırmaları Vakfı Yayınları, İstanbul.

Tanrıverdi, H. (2018), Din-Kültür İlişkisi Üzerine Bir Değerlendirme, Ordu Üniversitesi Sosyal Bilimler Araştırmaları Dergisi, 8(3), 595-601.

Taşbaş, E. (2018), Klasik Dönem Osmanlı Devlet ve Toplum Hayatında Dinin Yeri, Uluslararasi Sosyal Araştırmalar Dergisi, 11(57), 147-157.

Tayhani, İ. (2009), Türkiye Cumhuriyeti'nin Temeli: Lâiklik, Ankara Üniversitesi Türk Inkılâp Tarihi Enstitüsü Atatürk Yolu Dergisi, 43, 517-529.

Uğurlu, Serdar. (2012), Eski Türklerin Dini, Abant İzet Baysal Üniversitesi Sosyal Bilimler Enstitüsü Dergisi, 12(20), 323-335.

Yücel, İ. (1999), Diyanet İşleri Başkanlığı, Türkiye Diyanet Vakfi İslâm Ansiklopedisi, 9, 455-460. 